\title{
1. The middle-income transition challenge: an introduction
}

Juzhong Zhuang, Paul Vandenberg, and Yiping Huang

\subsection{ECONOMIC PERFORMANCE SINCE 1978}

By any measure, economic growth in the PRC since reforms began in the late 1970s has been spectacular. Gross domestic product (GDP) has expanded about 10 percent per annum on average (Figure 1.1), and per

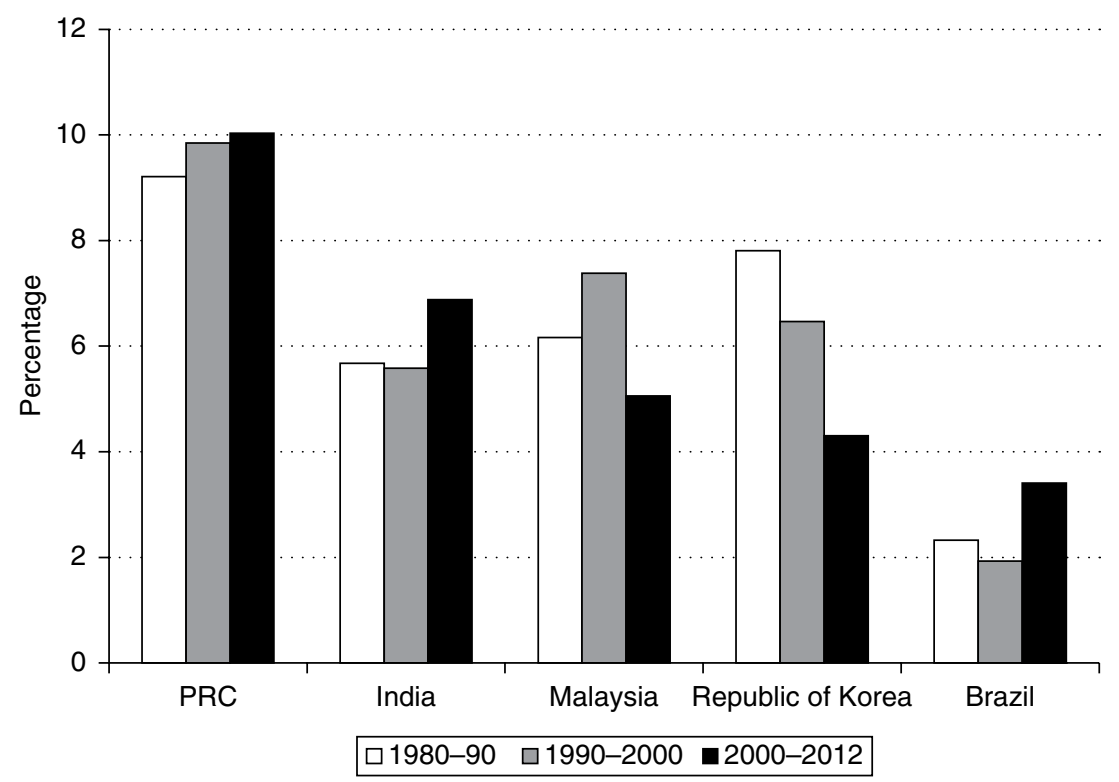

Note: $\quad$ GDP $=$ gross domestic product, PRC $=$ People's Republic of China.

Source: $\quad$ World Bank, World Development Indicators (accessed September 2013).

Figure 1.1 Average annual GDP growth, selected economies, 1980-2012 
Table 1.1 Per capita income and human development indicators, 1980-2012

\begin{tabular}{|c|c|c|c|c|c|c|c|}
\hline Indicators & 1980 & 1985 & 1990 & 1995 & 2000 & 2005 & 2012 \\
\hline Per capita GNI, current $\$$ & 220 & 280 & 330 & 530 & 930 & 1740 & 5720 \\
\hline $\begin{array}{l}\text { Per capita GNI, current } \\
\text { PPP \$ }\end{array}$ & 250 & 510 & 800 & 1490 & 2350 & 4090 & 9040 \\
\hline Per capita GDP, 2005 PPP \$ & 524 & 814 & 1101 & 1849 & 2667 & 4115 & 7958 \\
\hline $\begin{array}{l}\text { Poverty headcount ratio } \\
\text { at } \$ 1.25 \text { a day (PPP), \% of } \\
\text { population }\end{array}$ & $84^{\mathrm{a}}$ & $69^{b}$ & 60 & 54 & $36^{\mathrm{c}}$ & 16 & $12^{\mathrm{e}}$ \\
\hline $\begin{array}{l}\text { Poverty headcount ratio } \\
\text { at } \$ 2 \text { a day (PPP), } \% \text { of } \\
\text { population }\end{array}$ & $98^{\mathrm{a}}$ & $93^{b}$ & 85 & 74 & $61^{\mathrm{c}}$ & 37 & $27^{\mathrm{e}}$ \\
\hline $\begin{array}{l}\text { Life expectancy at birth, } \\
\text { years }\end{array}$ & 67 & 68 & 69 & 70 & 72 & 74 & $75^{\mathrm{f}}$ \\
\hline $\begin{array}{l}\text { Under } 5 \text { mortality rate, per } \\
\quad 1000\end{array}$ & 61 & 53 & 54 & 47 & 37 & 24 & 14 \\
\hline $\begin{array}{l}\text { Gross secondary enrollment, } \\
\%\end{array}$ & 44 & 32 & 38 & 51 & 58 & $67^{\mathrm{d}}$ & $87^{\mathrm{f}}$ \\
\hline Gross tertiary enrollment, $\%$ & 1 & 2 & 3 & 5 & 8 & 18 & $24^{\mathrm{f}}$ \\
\hline
\end{tabular}

Notes:

$\mathrm{GDP}=$ gross domestic product, $\mathrm{GNI}=$ gross national income, $\mathrm{PPP}=$ purchasing power parity, PRC = People's Republic of China.

a 1981 data, ${ }^{\text {b }} 1984$ data, ${ }^{\text {c }} 1999$ data, ${ }^{\text {d }} 2006$ data, ${ }^{\text {e }} 2009$ data, ${ }^{\text {f }} 2011$ data.

Gross enrollment ratio is the ratio of total enrollment, regardless of age, to the population of the age group that officially corresponds to the level of education shown.

Source: World Bank, World Development Indicators (accessed September 2013).

capita income has risen by a factor of 15 in constant 2005 purchasing power parity dollars (Table 1.1). From a very poor and agriculture-based economy, the country has reached upper middle-income status with a large manufacturing base. Quite justifiably, the PRC is called the workshop of the world.

Rapid growth and structural transformation have significantly reduced the country's poverty and improved the well-being and living standards of its people. When reforms began, 84 percent of the population lived below the $\$ 1.25$-a-day poverty line (Table 1.1). By 2009, that had fallen to 12 percent - an incredible achievement. Longevity increased from 67 years in 1980 to 75 years in 2011, and child mortality under the age of 5 years declined from 61 deaths per 1000 to 14 in the same period. These achievements have been replicated by very few developing economies; not 
surprisingly, the PRC's economic development is the envy of many emerging countries.

Rapid economic expansion has also led to a sharp rise in the country's importance globally. The PRC is now the world's largest trading nation, the largest holder of foreign reserves, and the second largest economy after the United States (US). What happens in the PRC matters greatly globally. The Millennium Development Goal of reducing global poverty by half will be achieved by 2015 largely because of the PRC's success in reducing its poverty rates. Also, the world economy recovered quickly from the 2008 global financial crisis because the PRC, India, and other emerging economies managed to sustain demand and growth - the PRC contributed more than one-third of global growth during 2008-12. Indeed, the current century can become an 'Asian century' only if the PRC along with India - continues to make rapid economic progress (Asian Development Bank 2011a). The PRC's influence on global economic policy and governance is also growing rapidly and will continue to do so.

\subsection{KEY DRIVERS OF ECONOMIC SUCCESS}

Three key factors have driven the PRC's economic transformation and social development: market-oriented reform, the most fundamental success factor; its low-cost advantage; and the role of the government. A range of other factors that helped create a virtuous cycle of growth and development was supportive in this process.

\subsubsection{Market-Oriented Reform}

The shift away from central planning allowed market forces to determine prices, enterprises to make production decisions based on demand and supply, and private businesses to compete in the marketplace. These changes unleashed powerful economic incentives and significantly improved the efficiency of resource allocation and utilization. At the same time, the government managed the reform process in a gradual and pragmatic manner. To quote former leader Deng Xiaoping, the government sought to 'cross the river by feeling the stones.' By doing so, the economy reformed and stability was ensured. For example, the PRC avoided the destabilization caused by the rapid, wholesale privatizations that contributed to economic crises in some transitional economies.

The liberalization of foreign trade and investment was a key aspect of this reform (Figure 1.2). Increased trade openness - culminating in accession to the World Trade Organization in 2001 - exposed PRC firms to 


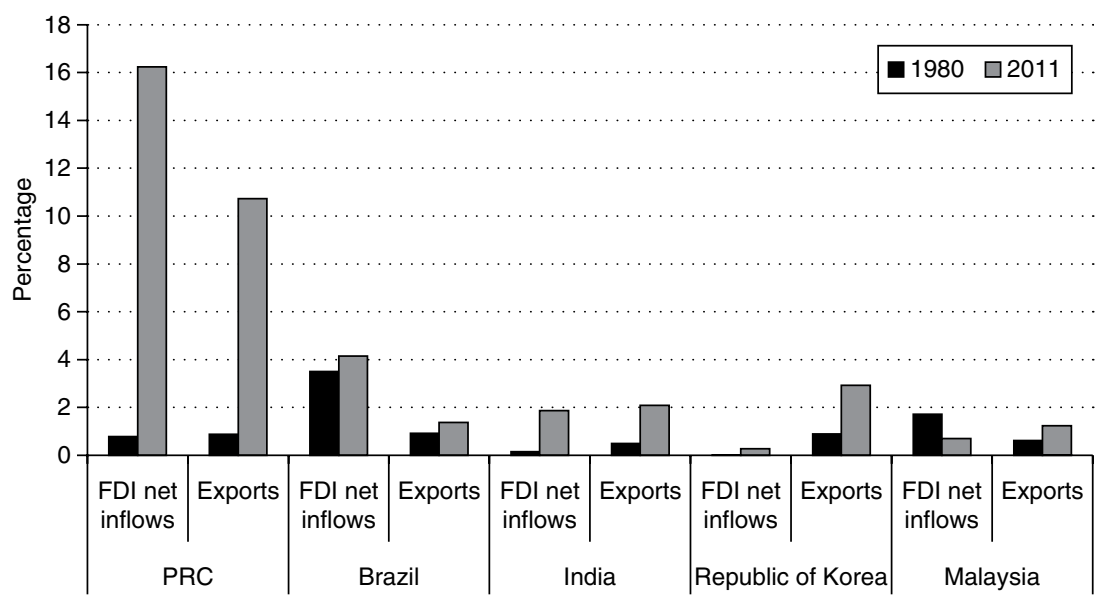

Notes:

FDI $=$ foreign direct investment, PRC $=$ People's Republic of China.

1980 FDI data for the PRC not available, 1982 used.

Exports consist of goods and services.

Source: World Bank, World Development Indicators (accessed August 2013).

Figure 1.2 Share of global exports and FDI, selected economies, 1980 and 2011

international competition and allowed them to explore their comparative advantage. It also opened doors to global markets, while offering economies of scale and access to needed capital goods and other resources. Foreign direct investment also played an important role in supporting industrial expansion, helping to improve export competitiveness by providing access to advanced technologies, management skills, and external capital. Also, the PRC's low-cost production base and a vast and expanding domestic market, in turn, attracted foreign direct investment.

\subsubsection{Low-Cost Advantage}

The second key driver of economic success was the PRC's low-cost advantage, largely the result of an immense supply of rural surplus labor, which is typical of a dual economy (Lewis 1954). This ensured a steady supply of low-cost labor for the modern, formal sectors in urban and industrial areas. Labor-intensive manufacturing and services grew rapidly, allowing firms to reinvest retained earnings in a classic pattern of development and structural transformation. The comparative advantage for any low- 


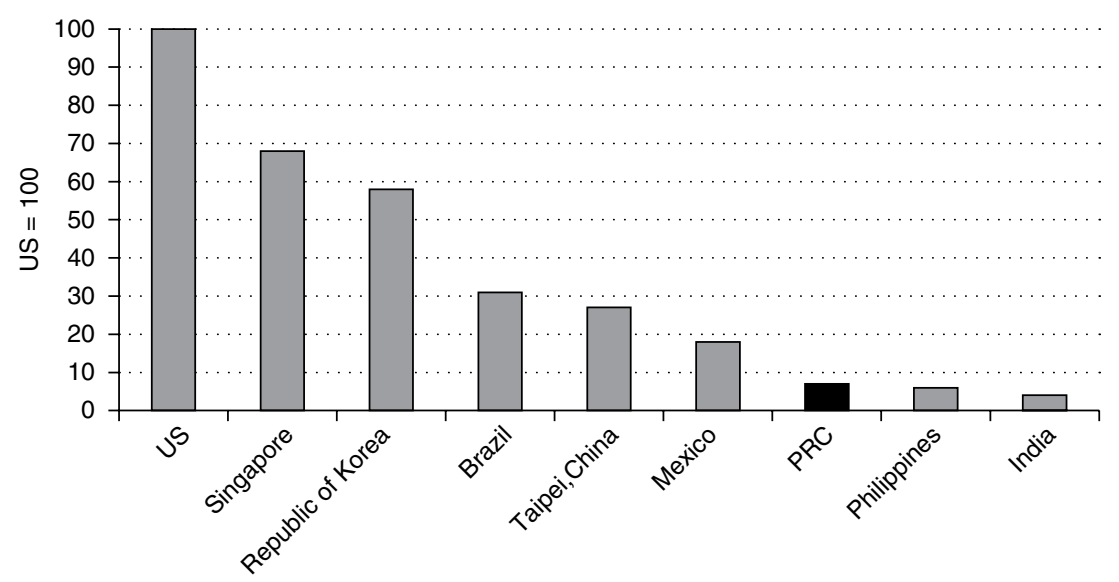

Notes:

PRC $=$ People's Republic of China, US $=$ United States.

The 2012 manufacturing labor compensation cost for the PRC is estimated from the 2009 figure obtained from the US Bureau of Labor Statistics, adjusted by the average urban wage growth and average percentage appreciation of the yuan against the dollar between 2009 and 2012.

The figure for India refers to 2007.

Source: US Bureau of Labor Statistics; National Bureau of Statistics, China Statistical Yearbook; People's Bank of China (accessed August 2013).

Figure 1.3 Index of hourly manufacturing labor compensation costs, selected economies, 2012

income country lies in producing goods that require low technology at low labor costs. As recently as 2012, hourly compensation rates in the PRC remained slightly above the Philippines, and considerably below those of more developed Asian economies and middle-income countries in Latin America (Figure 1.3).

To some extent, the PRC's low-cost advantage also developed out of asymmetric market liberalization. Here, approximately 90 percent of product market prices were fully liberalized, but the government still controlled prices in various factor markets to varying degrees (Huang 2010). For instance, low deposit interest rates combined with high household savings offered banks a steady flow of cheap funds. These savings were intermediated at low interest rates to enterprises, especially state-owned enterprises, enabling them to reap higher profits and thus increase corporate savings for investment. During 1990-2012, the PRC's average annual real lending rate was below 2 percent, among the lowest 


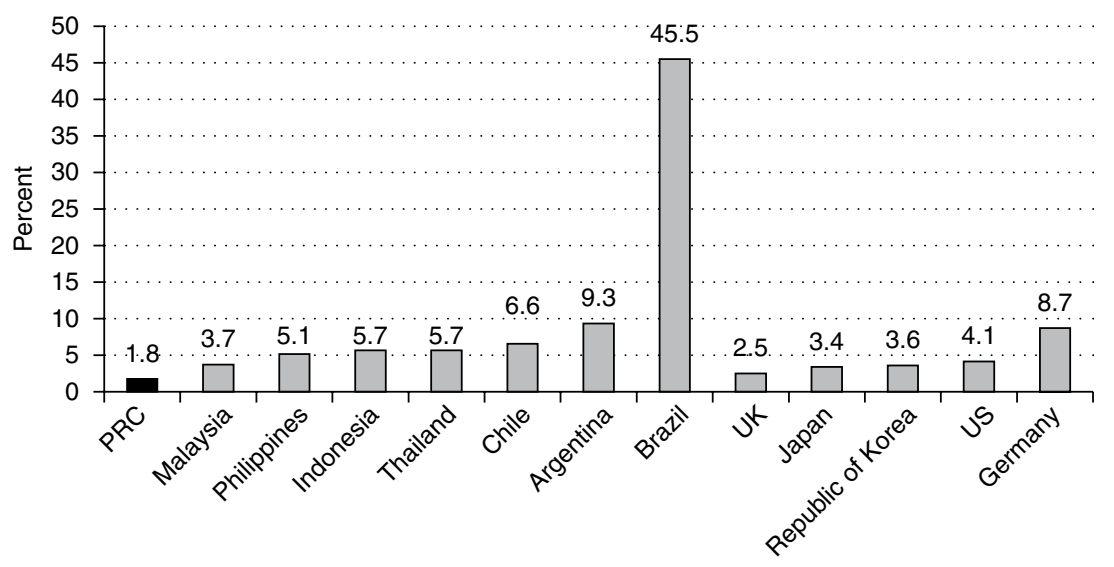

Notes:

PRC $=$ People's Republic of China, UK $=$ United Kingdom, US = United States. Real interest rate is the rate banks charge on loans to prime customers, adjusted for inflation.

Source: $\quad$ World Bank, World Development Indicators (accessed August 2013).

Figure 1.4 Annual average real interest rates, selected economies, 1990-2012

of 150 countries with available data, and well below most high- and middle-income countries (Figure 1.4). ${ }^{1}$ Furthermore, government-owned land was often allocated below market value to attract local investment. Energy prices were controlled for an extended period, although they have become more aligned with international prices in recent years (Rosen and Houser 2007).

\subsubsection{The Role of the Government}

Government played an important role in allocating resources as reforms were carried out, particularly in key production factors, such as capital, labor, land, energy, and raw materials. On the one hand, this reflects the PRC's long list of uncompleted reforms and is among the underlying causes of the structural imbalances discussed below. On the other hand, the government's proactive role in economic development has helped address some of the problems often associated with market failure, such as information and coordination externalities, especially in the context of structural transformation in developing countries (Hausmann and Rodrik 2003; Lin 2010). This is particularly true when considering that the 
PRC was emerging from a long period of central planning and was in the process of establishing effective market institutions.

The government has been effective in mobilizing resources needed for investment in public goods and services, particularly infrastructure, which are key conditions for rapid growth. In addition, decentralization provided local governments with strong incentives to promote local trade and investment through making access to credit and land easier, building infrastructure, and providing an environment conducive to businesses expansion and entrepreneurship (Huang 2010; Xu 2010; Yao 2010). ${ }^{2}$ In short, the government followed the path of other high-growth East Asian economies by committing to development, having a clear vision, possessing adequate tools for implementation, and using pragmatic policies and interventions. $^{3}$

\subsubsection{Other Success Factors}

Beyond the above drivers, other factors - some ingrained in the pre-reform economic fiber-played a critical role in supporting growth in the PRC. First, high household and corporate savings rates provided the funds for rapid investment. High levels of savings and investment also drove rapid economic expansion in other high-growth Asian economies during their take-off periods. In the PRC, total savings rose from below 36 percent of GDP in the early 1980 s to 53 percent by 2008 , despite repressed interest rates for savers. In 2008, households and the corporate sector contributed almost equally to savings at 23 percent and 22 percent, respectively (Table 1.2). While many middle-income countries strive to raise savings and investment rates, the concern in the PRC is that the level of investment is too high.

Second, a young, educated workforce enabled the PRC to benefit from a demographic dividend. This is now rapidly changing because of population aging (ADB 2011b), but it was a big boost to growth in the 1980s and 1990s. Education has expanded rapidly, providing human capital for more advanced, nonagricultural production. Secondary school gross enrollment rose steadily from 44 percent of the age cohort in the early years of reform to 87 percent by 2011 (Table 1.1). The expansion of tertiary education was even more dramatic, from less than 1 percent of the age cohort when reforms began to 24 percent in 2011.

Third, the massive expansion of quality infrastructure was an important spur to growth. The government invested heavily in transport, energy, telecommunications, and urban services. Many middle-income countries have seen infrastructure gaps develop and widen. However, with ample fiscal space and focused national and local governments, the PRC excelled 
Table 1.2 Savings rate, selected economies, 2008-09 (percentage of $G D P$ )

\begin{tabular}{|c|c|c|c|c|c|c|c|}
\hline & $\begin{array}{l}\text { PRC } \\
(2008)\end{array}$ & $\begin{array}{l}\text { India } \\
(2009)\end{array}$ & $\begin{array}{l}\text { Japan } \\
(2008)\end{array}$ & $\begin{array}{c}\text { Republic } \\
\text { of Korea } \\
(2009)\end{array}$ & $\begin{array}{c}\text { Germany } \\
(2009)\end{array}$ & $\begin{array}{c}\text { Mexico } \\
\text { (2009) }\end{array}$ & $\begin{array}{l}\text { United } \\
\text { States } \\
(2009)\end{array}$ \\
\hline $\begin{array}{l}\text { Total domestic } \\
\text { savings }\end{array}$ & 53.2 & 33.7 & 3.6 & 16.7 & 6.2 & 12.4 & -2.5 \\
\hline $\begin{array}{l}\text { Household } \\
\text { savings }\end{array}$ & 22.9 & 23.5 & 1.4 & 2 & 7.4 & 7.3 & 4.7 \\
\hline $\begin{array}{c}\text { Corporate } \\
\text { savings }\end{array}$ & 22.0 & 8.1 & 6.0 & 10.2 & 1.0 & 4.8 & 2.0 \\
\hline $\begin{array}{l}\text { Government } \\
\text { savings }\end{array}$ & 8.4 & 2.1 & -3.8 & 4.5 & -2.1 & 0.3 & -9.2 \\
\hline
\end{tabular}

Note: $\quad$ GDP $=$ gross domestic product, $\mathrm{PRC}=$ People's Republic of China.

Source: CEIC Data, Global Database; National Bureau of Statistics, China Statistical Yearbook; ADB staff estimates using GDP and savings data from OECD.Stat Extract (accessed June 2011).

in infrastructure development. From 1980 to 2012, total highway length more than quadrupled and electricity consumption per capita grew by a factor of nine (Figure 1.5).

Fourth, there was a reasonably comprehensive industrial and manufacturing base when economic reforms began-the result of pre-reform industrialization. Although it required technical modernization and better management, industry provided a solid base for expansion once reforms were launched. At that time, industry already accounted for over 45 percent of GDP. Although it dropped slightly during the 1980s, industry has remained between 45 percent and 50 percent of GDP since then.

Fifth, prudent macroeconomic management and a cautious approach to financial reform provided a stable investment climate. Also, limited capital account liberalization helped insulate the economy from global and regional financial contagion during crises. The effects on the PRC of the 1997-98 Asian financial crisis and the 2008-09 global financial crisis were fairly muted as the government applied effective countercyclical measures. Despite periodic spikes, inflation remained moderate during much of the reform period (Figure 1.6). The PRC avoided the hyperinflation that derailed growth in Latin America and afflicted other emerging markets. 


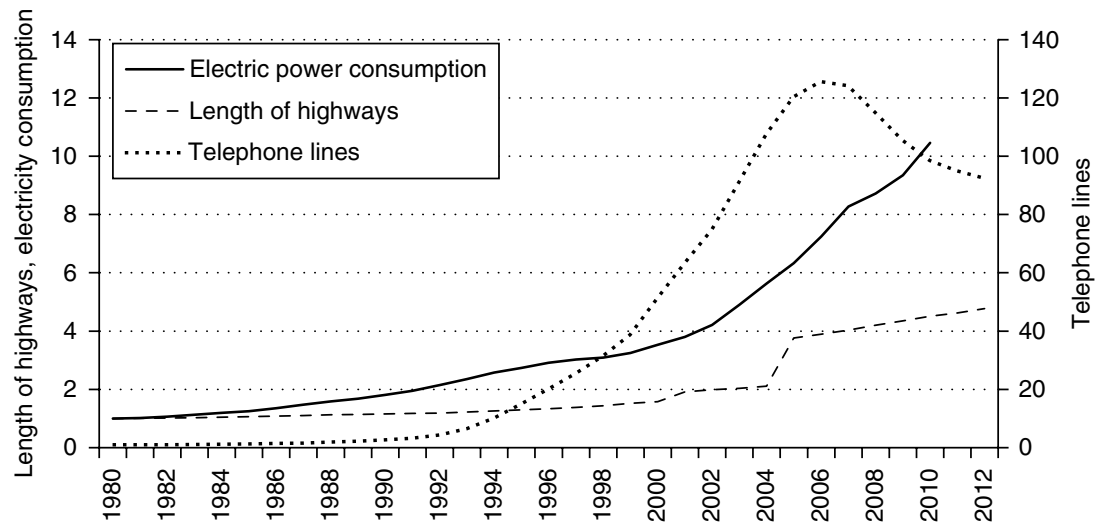

Source: World Bank, World Development Indicators; National Bureau of Statistics, China Statistical Yearbook (accessed July 2013).

Figure 1.5 Infrastructure development, 1980-2012 (1980=1)

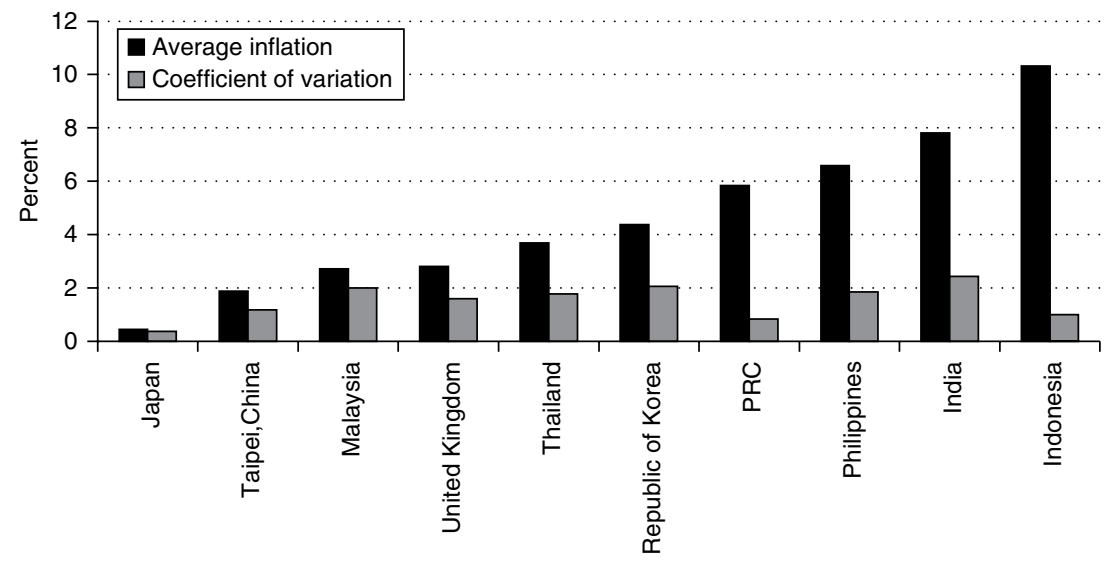

Notes:

PRC = People's Republic of China.

Data for the United Kingdom 1989-2012.

Source: World Bank, World Development Indicators; Asian Development Bank, Statistical Database System (accessed September 2013).

Figure 1.6 Average annual inflation, selected economies, 1987-2012 


\subsection{THE MIDDLE-INCOME TRANSITION CHALLENGE}

The PRC's impressive achievement should not obscure the major challenges that it faces. First, technological and productivity gaps with advanced economies remain large, despite significant gains in narrowing them. With a per capita gross national income of $\$ 5720$ in 2012, the country still has a long way to go before reaching high-income status.

Second, the PRC's rapid growth has benefited greatly from its low-cost advantage, especially in labor. However, with declining rural surplus labor and rising wages, growth will have to be increasingly driven by productivity improvement through innovation and industrial upgrading; achieving both will be necessary for the PRC to become a high-value economy.

Third, rapid growth has exposed several structural problems, in particular, imbalances in the sources of growth and rising income inequality. While to some extent these are often associated with a fast structural transformation, incomplete reform is a major contributing factor. If not addressed, these problems could hinder efforts to become a high-value economy.

Fourth, rapid growth has put enormous pressure on resources, particularly energy and water, and the environment.

International experience shows growth slowed significantly in many countries after they attained middle-income status, ${ }^{4}$ and they find it difficult to reach high-income status. ${ }^{5}$ Such countries are caught in what is commonly known as a middle-income trap. They can no longer compete with low-income countries because of rising wages, and they are unable to compete with high-income countries because they have not shifted into higher-value production through innovation and industrial upgrading.

Many Latin American and Southeast Asian countries are considered caught in the middle-income trap, falling into it $40-50$ years ago. Many of them will likely languish there for many years to come (Figure 1.7). While the PRC graduated from low- to middle-income status only in 1998, policymakers are increasingly concerned about sharing a similar fate.

\subsubsection{Defining the Middle-Income Trap}

An analysis of cross-country growth performance shows that 24 out of 125 countries globally have been at the middle-income stage continuously since 1987, the year the World Bank's income classifications were first introduced. ${ }^{6}$ The PRC is not part of this group as it was still a low-income country in that year. An extrapolation of the classification thresholds to earlier years indicates that 16 of those countries were middle income as 


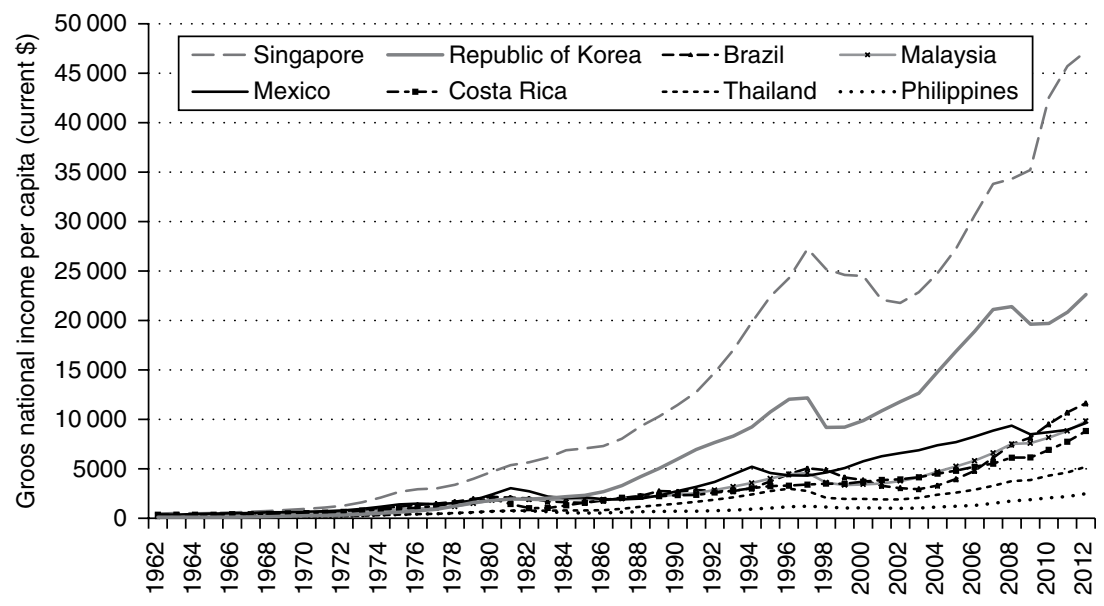

Source: World Bank, World Development Indicators (accessed August 2013).

Figure 1.7 Middle-income trap: Asia and Latin America, 1960-2012

early as 1962, meaning that they have been stuck at the middle-income stage for at least 50 years. $^{7}$ Nine of the 16 are in Latin America, three in Asia-Malaysia, the Philippines, and Thailand - with the remaining three in Africa and the Middle East. With the possible exception of Brazil and Malaysia, few of the 16 appear on their way to becoming high-income countries in the near future (Table 1.3).

The number of high-income countries globally is slightly larger, 35, based on the same criteria of having a population above 3 million. Among these, 18 moved from middle to high income after 1965, suggesting it has been possible in more recent decades to avoid the perils of middle income, structurally transform an economy, and grow above the high-income threshold. Eleven of these countries are in the European periphery, five are from East Asia, and two are from Latin America.

The most rapid transitions through the middle-income stage were in Asia. Japan emerged from World War II to reach high-income status in 1968 - taking just 23 years. The Republic of Korea moved from low to middle income just before 1962 and became high-income by 1994, taking 32 years. Taipei,China; Hong Kong, China; and Singapore were all firmly middle income in 1962 and became high-income economies in the 1970s and 1980s. Most of these economies lacked significant natural resources, but made a rapid transition to high-value manufacturing and services, and grew rapidly and consistently over many years. Singapore grew at an 
Table 1.3 High-and middle-income economies by regional groups

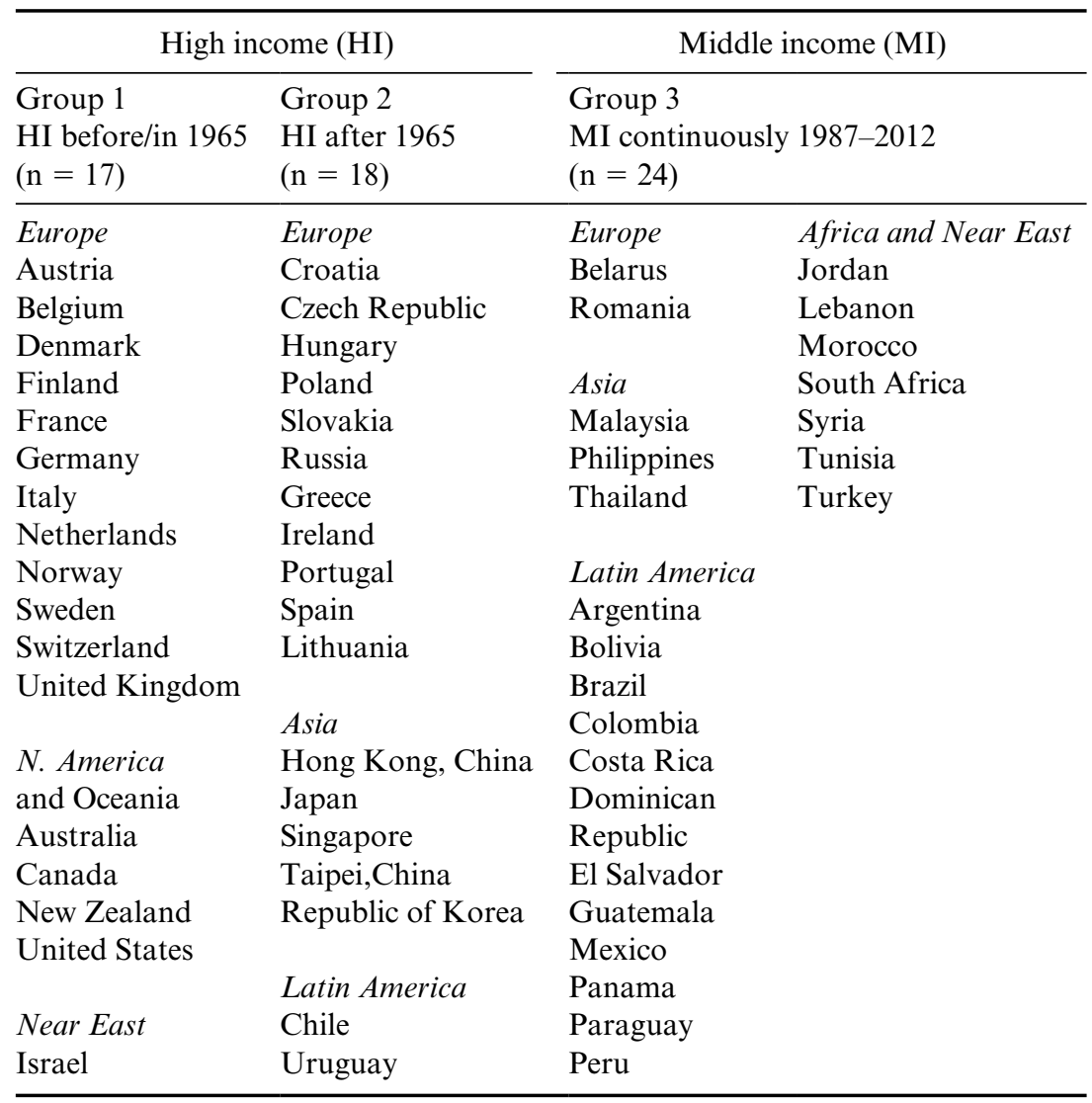

Note: Includes only countries with a population of 3 million or more; excludes members of the Organization of the Petroleum Exporting Countries.

Source: ADB staff calculations.

average annual rate of 11.9 percent in the ten years up to its graduation, and Japan grew by 9.9 percent a year in the seven years prior to attaining high-income status.

Although there is still no widely accepted definition of the middleincome trap, it is useful to link it to the dual-economy model of Arthur Lewis (1954). According to this, economic development is about structural transformation that entails shifting investment and labor from primary activities - notably farming - into urban-based manufacturing 


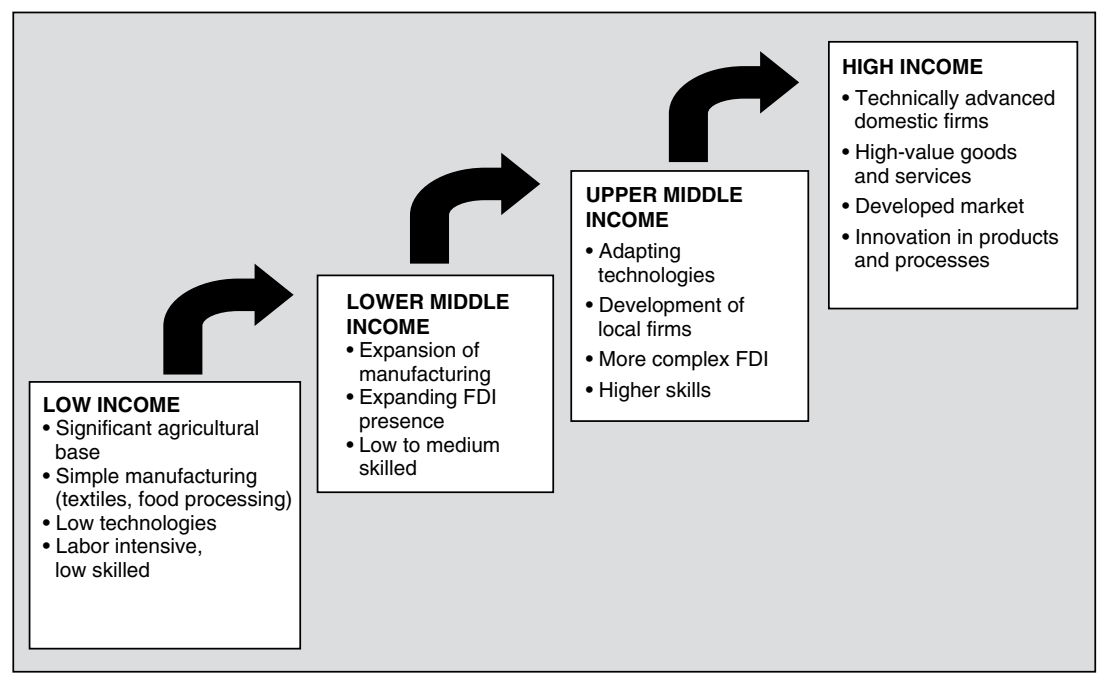

Note: $\quad$ FDI $=$ foreign direct investment.

Source: Authors.

Figure 1.8 The path to high-income status

and services over time. With a large supply of underutilized labor'unlimited' in Lewis's words - wages remain low as urban production expands, and business stays competitive at low cost. This productive structure employs low-level, established technologies which are easily imported and mastered locally. Simple machinery and processes produce simple, low-cost goods. Expanding the urban economy with no decrease in farm output allows total output to rise. As output rises faster than population, per capita income will rise. An economy enters the middle-income stage as production expands in labor-intensive manufacturing and services (Figure 1.8).

To boost output, the quality and value of production must rise with businesses catering to higher-value market segments and growth relying more on productivity improvement through innovation and industrial upgrading. If a country fails to do this, it will get caught in the middle.

\subsubsection{How to Avoid the Trap: Some Policy Lessons}

Fundamental to avoiding the middle-income trap is a country's ability to constantly innovate and upgrade production, raise productivity, and 
climb the value chain. This requires a critical mass of firms that are dynamic and with strong incentives to invest in and develop new and more advanced machinery, production processes, and products through research and development and innovation. Country experiences over the past five decades suggest that supporting innovation, upgrading, and transition toward a high-value economy also require government to create a conducive environment with the following four key elements.

The first is stability - macroeconomic, political, and social. Instability disrupts investment decisions, production planning, and market demand. Asian countries that grew rapidly and achieved high income created such stability (World Bank 1993), as did the 13 countries that sustained high growth over at least 25 years identified by the Commission on Growth and Development (2009). In contrast, hyperinflation, macroeconomic instability, debt crises, high income inequality, and political instability disrupted the growth performance of many Latin American countries and prevented them from moving beyond the middle-income stage (Lustig and Ros, Chapter 8 in this volume). Among the three Southeast Asia economies trapped since the early 1960 s, the Philippines suffered similar problems during the past three decades (ADB 2008).

The second is adequate public investment, notably in infrastructure and human capital. Firms need efficient transport systems to get inputs to factories and goods to markets, a reliable power supply for production, and good telecommunications. Without these, firms will find it hard to boost productivity and compete globally. Countries also require a skilled labor force to operate machines, manage production, and design better technologies. As an economy becomes more developed and seeks higher-value production, these public investments need to be more sophisticated. This means a more reliable and efficient infrastructure, and more highly skilled professionals, managers, and technical workers. East Asian countries ramped up education and training and improved infrastructure significantly in their run-up to high-income status.

The third is a well-functioning market system to allocate resources, organize production and trade, and provide price signals and incentives for producers and consumers. Experience has shown that a system of firms - predominately private - and market competition is most effective at organizing economic activity. This organization includes the necessary institutions to reassure investors and promote reliable and efficient transactions, notably the rule of law and protection of physical and intellectual property rights. Furthermore, an efficient financial system is needed to lubricate the wheels of investment, production, and trade. As with public investments, middle-income countries moving up the value chain require a more diversified and complex financial system, including a broadening of 
the sources of finance from financial institutions to financial markets, to manage risk and support investments in innovation.

The fourth is a focused industrial policy. Although this is a contentious area, the experience of some high-income countries, in particular the so-called miracle economies in East Asia, suggest that industrial policy plays an important role in successfully transforming an economy and avoiding the middle-income trap (Amsden 1989; Wade 1990; World Bank 1993). These policies involve sector- and industry-specific interventions to support innovation and upgrading. A broad range of industrial policy measures have been used by various countries, centering on areas including targeting priority industries, provision of subsidized credit, trade policy, support for research and development, state ownership, and information sharing. Such instruments are designed to overcome market failures - in particular, information and coordination externalities - inherent in the development process and particularly acute in innovation, upgrading, and structural transformation (Hausmann and Rodrik 2003; Rodrik 2004; Lin 2010).

However, for a long time, industrial policy was discredited, in part owing to poor design and implementation in many countries, but also by the Washington Consensus ideology under which privatization, liberalization, the free market, and minimal state intervention were the norm. Industrial policy has received renewed attention lately, partly because policies based solely on free markets and liberalization were not effective in achieving high growth in many countries in the 1980s and 1990s, especially in Latin America. The PRC's economic success also shows that government can play an important role, especially in urging structural transformation where the market alone is not sufficient (Rodrik 2004; Lin 2010). Furthermore, many believe that excessive reliance on unfettered markets helped cause the recent global financial crisis (Stiglitz 2010). While the Washington Consensus has grown out of fashion, the debate on the merits and scope of industrial policy continues. However, its focus appears to have shifted from whether or not industrial policy should be used to how it can be better designed and implemented (Box 1.1). ${ }^{8}$

The above discussions highlight some of the broad policy lessons drawn from country experiences. However, in designing policies for avoiding the middle-income trap, it is important to note that countries have different circumstances and confront a unique set of challenges and risks. Therefore, the needed policy options are likely to be country specific. In the case of the PRC, its large productivity and technology gaps with advanced countries and rising wages mean that the danger of getting caught in a middle-income trap is real. At the same time, incomplete reforms, which contribute to low-cost advantage, have created various 


\section{BOX 1.1 HOW TO DESIGN INDUSTRIAL POLICY}

Economists and policymakers are looking at industrial policy for the important role that it can play in addressing market failures. This is especially so for failures related to information and coordination externalities, which are particularly pervasive in the development or adoption of new technologies, products, and markets. While the industrial policy debate is likely to continue, its focus is shifting from whether it is needed to how it should be designed and implemented.

Rodrik $(2004,2007)$ argues that industrial policy is not about subsidies, but about public-private collaboration to address market failures and providing the missing public inputs that the private sector needs to function effectively. For Rodrik, a change in the framework for formulating industrial policy is needed to 'maximize its potential to contribute to economic growth while minimizing the risks that it will generate waste and rent-seeking.' The emphasis should be on self-discovery of the potential to enter into high-technology and higher-value industries and on assisting in addressing coordination failures inherent in structural transformation.

Rodrik argues that the standard instruments of industrial policy-credit and fiscal support and infrastructure provision, among others-can be improved if they are deployed in a more productive manner. To do this, he proposes ten design principles for industrial policy:

- incentives provided only to 'new' activities;

- clear benchmarks and criteria for success and failure;

- built-in sunset clauses;

- public support that targets activities and not sectors;

- activities that are subsidized have clear potential for spillover and demonstration effects;

- the authority for carrying out industrial policy is vested in agencies with demonstrated competence;

- implementing agencies are monitored closely by a principal with a clear stake in the outcome and who holds political authority at the highest level;

- the agencies carrying out promotions maintain channels of communication with the private sector;

- the objective should not be to minimize the chances that mistakes will occur-which would result in no self-discovery at all-but to minimize the costs of the mistakes when they do occur; and

- promotion needs to be renewable so the cycle of discovery continues.

While these provide broad principles to guide the implementation of industrial policy, the right policy mix will differ by circumstance and country. Any effective strategy is likely to be country-specific, as there is no one-size-fits-all solution.

forms of economic imbalance, led to inefficiencies and the misallocation of resources, and contributed to rising inequality. One way or another, these could potentially weaken firms' incentives to innovate and upgrade, hinder the development of the country's innovation capabilities, affect 
economic and social stability, and undermine the sustainability of growth. Policymakers also need to respond to resource constraints, environmental challenges, and a more complex external economic environment.

\subsection{PURPOSE AND ORGANIZATION OF THIS BOOK}

Managing the Middle-Income Transition evolved out of two interrelated concerns: that the PRC's economic model may be at a crossroads, and that the health of the world's second-largest economy matters for the welfare of the global economy. The PRC's model, based on high investment, exports, low-cost advantage, and government interventions, has been successful in transforming the country from a low-income to an upper middle-income economy. But it has also generated contradictions that could undermine future growth. Further transition from an upper middle-income to a high-income economy requires a far greater reliance on innovation, productivity and efficiency improvement, market forces, and competition. The concern over the sustainability of the current model is shared not only by many of the authors of this book, but also by other researchers, economists, experts within the PRC and abroad and, in recent years, by policymakers and the PRC's senior leadership. The latest government response is the adoption of the 'Decisions on Major Issues Concerning Comprehensively Deepening Reforms at the Third Plenum' by the 18th Central Committee of Chinese Communist Party in November 2013.

The book, consisting of four parts, is an attempt to come to terms with the Chinese juggernaut, both its strengths and its weaknesses, and to offer policy suggestions to place the economy on a more stable footing and ensure that its robust growth can be sustained. The first part provides an overview and synthesis of the key issues. The second part focuses on issues related to reform and rebalancing in national and global perspectives. The third looks at macroeconomic and structural challenges, and the fourth part examines social, demographic, and environmental issues. Highlights of each chapter are summarized below.

In Chapter 2, Juzhong Zhuang, Paul Vandenberg, and Yiping Huang discuss the six challenges most critical for sustaining growth, including the PRC's large technology and productivity gaps with advanced countries, rising wages, imbalances in the sources of growth, rising income inequality, resource constraints and environmental degradation, and the challenging external economic environment.

In Chapter 3, the same authors contend that, to address these challenges, the PRC needs a development strategy that tilts the balance from 
low-cost to high-value production, from reliance on government to the use of market forces and competition, from investment to private consumption, from external to domestic demand, from targeting growth alone to both growth and distribution, and from a development-centric approach to one that matches development with environmental protection. The authors identify the broad policy directions and options for each of these strategic priorities.

A look at the reform and rebalancing issues in national and global perspectives in Part II opens with Yiping Huang in Chapter 4 focusing on three questions related to the sustainability of economic growth in the PRC. What contributed to the unusual combination of economic miracle and growing structural risks during the reform period? What changes are required for achieving the key policy goal of transforming the economic development pattern? What are the desirable macroeconomic and financial policy frameworks for facilitating rapid growth in the coming decades? Huang argues that avoiding the middle-income trap requires changing the pattern of economic development.

Yang Yao, in Chapter 5, reviews the role of the government in the PRC's dramatic growth and explores the challenges that it faces to maintain a positive role for sustainable growth. Yao shows that the "productionoriented' government has aggravated economic imbalances through the implementation of policies entailing subsidies to capital.

Ligang Song, in Chapter 6, discusses the PRC's growing economic role on the world stage and the emerging challenges in its integration with the global economy. He emphasizes that comprehensive institutional reform will be needed for the country to become a major driver of deepening global and regional economic integration. Song concludes that failure to do this will jeopardize growth and integration into global markets, risking dislocation in the domestic economy and social instability.

In Chapter 7, Wing Thye Woo reviews the global record on catch-up growth in the last 50 years and introduces an index to assess whether a country was catching up during 1960-2008 relative to the US. He compares the PRC with three groups of countries at different stages of growth to identify potential barriers to continued high growth. Drawing lessons for the PRC, he explores the experiences of Indonesia and Malaysia.

Chapter 8 by Nora Lustig and Jaime Ros looks at how Latin America's experience in the areas of macroeconomic management and social policy can provide useful lessons for the PRC and other emerging economies.

Part III opens with Yolanda Fernandez Lommen and L. Randall Wray, in Chapter 9, examining the fiscal and monetary policy options available to the PRC as a sovereign currency-issuing nation operating in a US dollar-standard world. The authors recommend that the central 
government's fiscal stance should be relaxed so that local government and corporate budgets can be tightened, helping to avoid depressing growth or sparking excessive inflation.

In Chapter 10, Kang Jia and Junmin Liu assess the sustainability of the PRC's current fiscal position in light of economic growth prospects and the main risk factors. They offer recommendations for strengthening public finances and achieving fiscal sustainability.

Loren Brandt, in Chapter 11, clarifies the definition of industrial upgrading and identifies the factors that influence its pace. He reviews the role of strategic industrial policy and lessons from successful East Asia industrialization and considers the pattern of industrial upgrading in the PRC.

Paul Vandenberg, in Chapter 12, asserts that the only way for the PRC to escape the middle-income trap is by moving up the value chain and producing more sophisticated goods and services with advanced technology. To this end, the government is focusing on promoting 'indigenous innovation.' Private domestic firms, state-owned enterprises, and foreign firms all have a role to play in the transformation of productive activity, with further upgrading coming from the most innovative players.

In Chapter 13, Jianguo Xu identifies a range of factors that have contributed to the significant underdevelopment of the PRC's services sector. He proposes a number of policy options to move the economy away from excessive reliance on industry, including eliminating the policy bias that favors manufacturing and goods exports and relaxing regulatory barriers in key services sectors.

Lixing $\mathrm{Li}$, in Chapter 14, argues that urbanization will remain a driving force in the PRC's sustained growth over the next 20 years and will be key for rural development and providing funds for the modernization of agriculture.

In Part IV, Guanghua Wan and Juzhong Zhuang in Chapter 15 piece together an overall picture of income inequality in the PRC during 1978-2012 using estimates from various sources. They argue that marketoriented reform, integration with the global economy, and technological change-ironically the three major factors underlying the PRC's rapid economic growth - together explain a large part of the increase in inequality, and that unequal access to opportunity in various dimensions owing to incomplete reform is compounding the problem. Wan and Zhuang recommend policy options for addressing rising inequality and for making economic growth more inclusive.

Fang Cai in Chapter 16 looks at the demographic transition and the PRC's experience in approaching its Lewis turning point, which is snaring the country in the middle-income trap. He argues for a wide range of 
reforms to allow the PRC to transform its pattern of economic growth from inputs driven to productivity driven, improve income distribution and household consumption, and balance the future population in terms of age structure and quality of the labor force.

In Chapter 17, Meiyan Wang stresses the need for the PRC to address its pressing educational and human capital needs to avoid the middleincome trap. Industrial upgrading will require a better trained workforce than was needed for labor-intensive manufacturing.

In Chapter 18, Xiaoyan Lei, Chuanchuan Zhang, and Yaohui Zhao analyze the changing demographics of Chinese society and the government's pension programs and income guarantees. They provide alternative scenario projections on the returns earned on pension funds, contribution rates, and subsidies from government, which are needed to ensure that pension liabilities do not become a time bomb.

Chapter 19 closes the book, with Yi Jiang and Jingmin Huang taking a quantitative approach to understanding the water scarcity challenge now and in the future. They estimate the water supply-demand gap over the next three decades, and demonstrate how urban water services, water pricing, and household water use will become critical in managing this precious resource.

\section{NOTES}

1. The combination of a high savings rate and low returns to savers also characterized other East Asian economies during high-growth periods (World Bank 1993).

2. Some scholars characterize the PRC's local governments as 'production oriented' in that they manage local economies like corporations (Huang 2010; Yao 2010). Local government units were in fact production oriented in the pre-reform period. The difference since the late 1970s was in combining government direction with market forces.

3. Many refer to the PRC development model as the 'Beijing Consensus,' one of the features being the combination of market forces with government planning (for example, see Li et al. 2009).

4. The latest income thresholds (gross national income per capita) used by the World Bank in classifying economies are in 2013 dollars, calculated using the Atlas method. These are: low income, $\$ 1035$ or below; lower middle income, $\$ 1036-\$ 4085$; upper middle income, \$4086-\$12615; and high income, \$12616 or above.

5. For a recent account of cross-country experiences of growth slowdowns, see Eichengreen et al. (2011) and ADB (2011c).

6. The 125 countries and territories covered in the World Bank's World Development Indicators database exclude members of the Organization of the Petroleum Exporting Countries and those with populations below 3 million in 2008.

7. The other eight countries may have been middle-income countries in 1962, but reliable comparable data on current gross national income per capita using the Atlas method are not available.

8. Even developed countries such as the United Kingdom and the US are looking to industrial policy as a way to revive and boost manufacturing capacity (Economist 2011). 


\section{REFERENCES}

Amsden, A. (1989), Asia's Next Giant: Korea and Late Industrialization, Oxford: Oxford University Press.

Asian Development Bank (ADB) (2008), Critical Development Constraints in the Philippines, Manila: ADB.

Asian Development Bank (ADB) (2011a), Asia 2050: Realizing the Asian Century, Manila: ADB.

Asian Development Bank (ADB) (2011b), Asia Economic Monitor, Manila: ADB.

Asian Development Bank (ADB) (2011c), 'Slowdown of fast-growing economies: international evidence and implications for the Peoples' Republic of China', Observations and Suggestions, No. 2011-5, Beijing: ADB-PRC Resident Mission.

Commission on Growth and Development (2009), 'Post-crisis growth in developing countries: a special report of the Commission on Growth and Development on the implications of the 2008 financial crisis', International Bank for Reconstruction and Development and World Bank, Washington, DC.

Economist, (2011), 'The global revival of industrial policy: picking winners, saving losers', The Economist, 5 August.

Eichengreen, B., D. Park, and K. Shin (2011), 'When fast growing economies slow down: international evidence and implications for the People's Republic of China', ADB Economics Working Paper Series No. 262, ADB, Manila.

Hausmann, R. and D. Rodrik (2003), 'Economic development as self-discovery', Journal of Development Economics, 72 (2), 603-33.

Huang, Y. (2010), 'China's great ascendancy and structural risks: consequences of asymmetric market liberalization', Asian Pacific Economic Literature, 24 (1), $65-85$.

Lewis, A. (1954), 'Economic development with unlimited supplies of labor', Manchester School of Economic and Social Studies, 22 (2), 139-91.

Li, X., K.E. Brødsgaard, and M. Jacobsen (2009), 'Redefining Beijing consensus: ten economic principles', China Economic Journal, 2 (3), 297-311.

Lin, J.Y. (2010), 'New structural economics: a framework for rethinking development', World Bank Policy Research Working Paper No.5197, World Bank, Washington, DC.

National Bureau of Statistics (various years), China Statistical Yearbook, Beijing: Social Sciences Academic Press.

Rodrik, D. (2004), 'Industrial policy for the twenty-first century', Working Paper Series No. rwp04-047, John F. Kennedy School of Government, Harvard University, Cambridge, MA.

Rodrik, D. (2007), 'Normalizing industrial policy', paper for the Commission on Growth and Development, John F. Kennedy School of Government, Harvard University, Cambridge, MA.

Rosen, D.H. and T. Houser (2007), 'China energy: a guide for the perplexed', China Balance Sheet, a joint project by the Center for Strategic and International Studies and the Peterson Institute for International Economics, available at: http://www.iie.com/publications/papers/rosen0507.pdf (accessed 5 January 2014).

Stiglitz, J. (2010), Freefall: America, Free Markets and the Sinking of the World Economy, New York: Norton. 
Wade, R. (1990), Governing the Market: Economic Theory and the Role of Government in East Asia's Industrialization, Princeton, NJ: Princeton University Press.

World Bank (1993), 'The East Asian miracle: economic growth and public policy', World Bank Policy Research Report, New York: Oxford University Press.

$\mathrm{Xu}, \mathrm{G}$. (2010), 'State-owned enterprises in China: how big are they?', available at: http://blogs.worldbank.org/eastasiapacific/state-owned-enterprises-in-chinahow-big-are-they (accessed 5 January 2014).

Yao, Y. (2010), 'China's export-led growth model: cause, prospects and structural issues', China Center for Economic Research, Beijing.

\section{Websites}

Asian Development Bank (ADB), Statistical Database System: https://sdbs.adb. org/sdbs/index.jsp

CEIC Data, Global Database: http://www.ceicdata.com/

Organisation for Economic Co-operation and Development (OECD), OECD.Stat Extract: http://stats.oecd.org/

People's Bank of China: http://www.pbc.gov.cn/publish/english/1140/index.html

US Bureau of Labor Statistics, International Labor Comparison: http://www.bls. gov/fls/

World Bank, World Development Indicators: http://data.worldbank.org/ 